\title{
Research on chronic noncommunicable diseases in Brazil: meeting the challenges of epidemiologic transition
}

\author{
Erly C. Moura, ${ }^{1}$ Leonor M. Pacheco-Santos, ${ }^{2}$ Lilian R. Peters, ${ }^{3}$ \\ Suzanne J. Serruya, ${ }^{4}$ and Reinaldo Guimarães ${ }^{5}$
}

Suggested citation

Moura EC, Pacheco-Santos LM, Peters LR, Serruya SJ, Guimarães R. Research on chronic noncommunicable diseases in Brazil: meeting the challenges of epidemiologic transition. Rev Panam Salud Publica. 2012;31(3):240-5.

ABSTRACT In Brazil, chronic noncommunicable diseases (CNCDs) are the leading cause of death and a major contributor to the national disease burden. This article describes CNCD research funded by the Ministry of Health Department of Science and Technology (DECIT) to support the production and dissemination of scientific evidence for the national health system, in accordance with the National Agenda of Priorities in Health Research, and within the context of Brazil's epidemiologic transition.

Data were obtained from Ministry of Health database management systems. CNCD-related projects financed by DECIT from 2002 to 2009 were analyzed by research theme (cancer, obesity, hypertension, diabetes, cardiovascular diseases, CNCDs in general, and CNCD risk factors) and geographic region.

In terms of funding and number of projects, the most-supported research theme was cancer, and the most-supported region was the Southeast. Project type varied widely, ranging from basic scientific studies to highly technological research and development. Results obtained included epidemiologic profiles and surveillance, cost, and quality-of-life data.

Key words Chronic disease; health policy; health research policy; information systems; health transition; Brazil.

The primary challenge of the Department of Science and Technology (DECIT) at Brazil's Ministry of Health is to guarantee scientific and technological development as an important and permanent tool for guiding the country toward an

\footnotetext{
1 Ministério da Saúde, Brasília, DF, Brazil. Send correspondence to: Erly Catarina Moura, erly.moura@saude.gov.br, erlycm@usp.br

2 Departamento de Saúde Coletiva, Universidade de Brasília, Brasília, DF, Brazil.

3 Ministério da Ciência e Tecnologia, Brasília, DF, Brazil.

4 Centro Latino-americano de Perinatologia / Saúde da Mulher e Reprodutiva da Organização Panamericana da Saúde, Montevideo, Uruguay.

5 Universidade do Estado do Rio de Janeiro, RJ, Brazil.
}

evidence-based national health system that promotes universality, integrity, and equity. DECIT has established various partnerships for this purpose, pooling resources with the agencies of the Ministry of Science and Technology as well as the 27 Foundations for Research Support (Fundações de Amparo à Pesquisa, FAPs) from Brazil's federal states.

Brazil's National Policy on Science, Technology, and Innovation in Health (Politica Nacional de Ciência, Tecnologia e Inovaçãa em Saúde, PNCTI/S) aims to provide scientific evidence to support health promotion and disease prevention, treatment, and recovery, based on human rights and ethical principles. The establishment of the National Agenda of Priorities in Health Research (NAPHR) was fundamental for reaching this goal. The process began in June 2003 and was finalized during the 2nd National Conference on Science, Technology, and Innovation in Health, held in July 2004, when both the National Policy and the Agenda were presented, discussed, and approved (1). The conference provided a forum for the first in-depth interaction among scientists and community leaders (1). Chronic noncommunicable diseases (CNCDs) were designated as one of the 24 approved sub-agendas. 
CNCDs are characterized by multiple and common risk factors, a similar and long duration of clinical history, and preventability, and mainly comprise the cardiovascular diseases (heart disease and stroke), some cancers, and diabetes. The World Health Organization (WHO) has listed tobacco consumption, binge drinking, being overweight, hypertension, and high blood cholesterol among the risk factors related to CNCDs (2).

WHO estimates that more than $60 \%$ of all deaths worldwide are caused by CNCDs, and approximately $70 \%$ occur in Latin American and Caribbean countries (2). In Brazil, CNCDs account for $60 \%$ of all deaths and about $40 \%$ of the disease burden. In 2010, the Ministry of Health estimated a high prevalence of CNCD risk factors among adults (3), including low consumption of vegetables $(81.8 \%)$, being overweight $(48.1 \%)$, smoking (15.1\%), binge drinking (18.0\%), and sedentary lifestyle (14.2\%).

This article describes the range of CNCD research funding by DECIT to help illustrate how the country is responding to this problem. The following questions are addressed: 1) Which research themes are mostly commonly selected for study? 2) How is funding distributed by geographic region? 3) How are research themes distributed by geographic region? 4) What are the main types of research projects? and 5) What type of results are obtained?

Information was obtained from the two Ministry of Health database management systems used to register projects funded by DECIT from 2002 to 2009: "PesquisaSaude"6 (designed to provide transparency and accountability to DECIT processes), and $\mathrm{SisCT}^{7}$ (designed for internal use in awarding grants). For each of the 3807 projects, the systems provided the following data components: type of call for proposal; title; abstract; key words; sub-agenda; type and nature of the research; sector of application; principal investigator (name, contact, affiliation); year; types of support; partnerships; and resources approved.

A search was conducted across the first four data component fields (subagenda, title, abstract, and key words) for seven CNCD research themes: 1)

\footnotetext{
6 http://www.saude.gov.br/pesquisasaude http://www.saude.gov.br/sisct
}

cardiovascular diseases; 2) cancer; 3) obesity; 4) hypertension; 5) diabetes; 6) CNCDs in general; and 7) CNCD risk factors (being overweight, poor dietary habits, low physical activity, and tobacco and alcohol consumption). One of the authors (ECM) was responsible for the classification of all CNCD projects by theme. A total of $639 \mathrm{CNCD}$ projects were identified and analyzed.

Summaries of various studies were prepared and included in the study results to illustrate the range of projects funded by DECIT within the context of both the NAPHR mandate and Brazil's current health situation, which meets the criteria for epidemiologic transition.

Among all CNCD projects, cancer was the research theme most supported by DECIT in terms of resource allocation and number of projects. Other than cancer, the three most common subjects were hypertension, CNCDs in general, and cardiovascular diseases (by resource allocation), and diabetes, hypertension, and CNCD risk factors (by number of projects).

Due to the country's size and cultural and epidemiologic diversity, CNCD research distribution was also analyzed by region, even though many studies were not region-focused (e.g., many projects funded to investigators from the Southeast were national studies). The criterion used to classify each study by region was the location of its principal investigator.

Analyzing research themes by region, allocated resources favored cardiovascular diseases in the North; cancer in the Northeast, Midwest, and Southeast; and diabetes in the South. In terms of number of projects, DECIT's largest investment went to cancer research across all regions (Figure 1).

For all regions, Figure 2 shows the percentage distribution of the Brazilian population (estimated at 191481045 for 2009); mortality due to circulatory diseases and cancers (469 957 for 2007); approved CNCD projects (639 from 2002 to 2009) and research funding (US\$ 82 million from 2002 to 2009); and gross national product (GNP) (estimated at US\$ 1572 billion for 2009). Across all regions, DECIT funding for $\mathrm{CNCD}$ research was greatest in the Southeast, even when considered in proportion to population size, due to reasons cited below.

Cardiovascular diseases are the main cause of death in the country, compris- ing almost $30 \%$ of all mortality cases, afflicting more than $5 \%$ of people aged 35 years and older, and resulting in hospitalization costs equal to more than $0.5 \%$ of the GNP (4). From 2002 to 2009, US\$ 14387093 was invested by DECIT and its partners in cardiovascular diseases. In 2004, US\$ 6.3 million $^{8}$ was granted for the MiHeart Study (Multicenter Randomized Cell Therapy Trial in Cardiopathies), one of the world's largest stem cell clinical trials for heart disease. The publication describing the protocol is a "highly accessed" report published in Trials, a specialized scientific journal (5). The Brazilian effort in this novel area of stem cell research was recently classified as innovative by an independent study (6). Another US\$ 4.1 million was invested in a research and development (R\&D) project to build out a prototype of a cardiac pacemaker.

Cancer is the second most common cause of death in Brazil, representing $17 \%$ of all deaths by known causes in 2007. Fighting this disease requires knowledge of topics ranging from the complex mechanisms of cellular/molecular regulation to lifestyle habits, and use of available high-quality resources and evaluation tools that aid in reducing cancer incidence and mortality. Investments in cancer research by DECIT and its partners totaled US\$ 24 million from 2002 to 2009. Cancer incidence is $4.1 \%$ higher among women (253.23 cases per 100000 individuals) versus men (243.77 per 100000 individuals). Of the 500000 new cases expected in 2010, the most common types are nonmelanoma skin cancer $(23.9 \%$ among females and $22.6 \%$ among males); prostate cancer $(22.2 \%$ among men); and breast cancer $(19.4 \%$ among women) in 2010 (7).

Cancer research projects supported by DECIT target both male and female subjects and comprise a variety of specialties (breast, head, leukemia, liver, lung, neck, oral, prostate, and uterus); areas of expertise (bioinformatics, education, nutrition, pharmacology, and health services); age groups; and locations. They also cover various different areas of study, ranging from epidemiologic studies of risk factors to the development of new diagnostic technologies (e.g., biomarker, genome profiling, and imaging) and treatments. In 2006, DECIT and

\footnotetext{
US\$1 = R\$1.7162 (September 2010).
} 
FIGURE 1. Distribution (\%) of chronic noncommunicable disease (CNCD) research projects and funding by subject and geographic region, Brazil, 2002-2009

PROJECTS

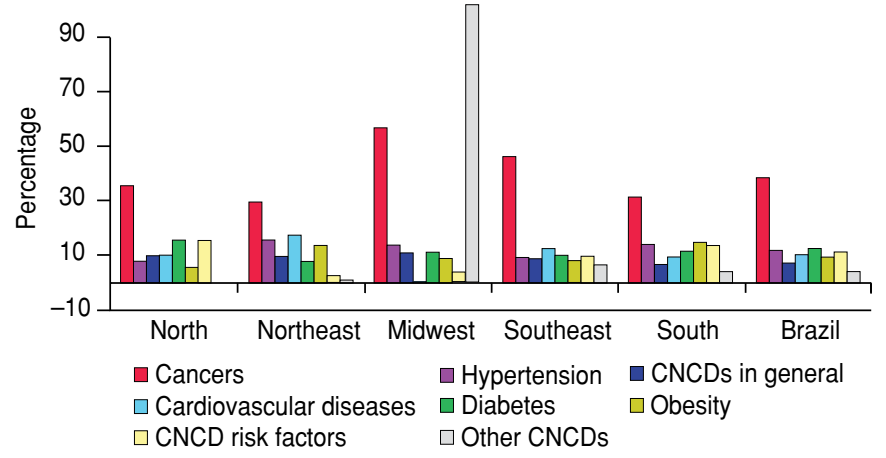

FUNDING

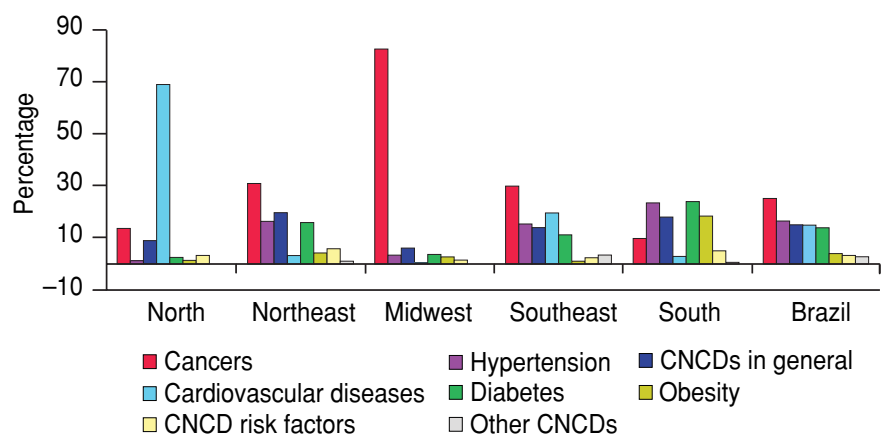

FIGURE 2. Distribution (\%) of chronic noncommunicable disease (CNCD) research projects and funding, mortality due to circulatory diseases and cancers, national population, and gross national product (GNP), by geographic region, Brazil, 2002-2009

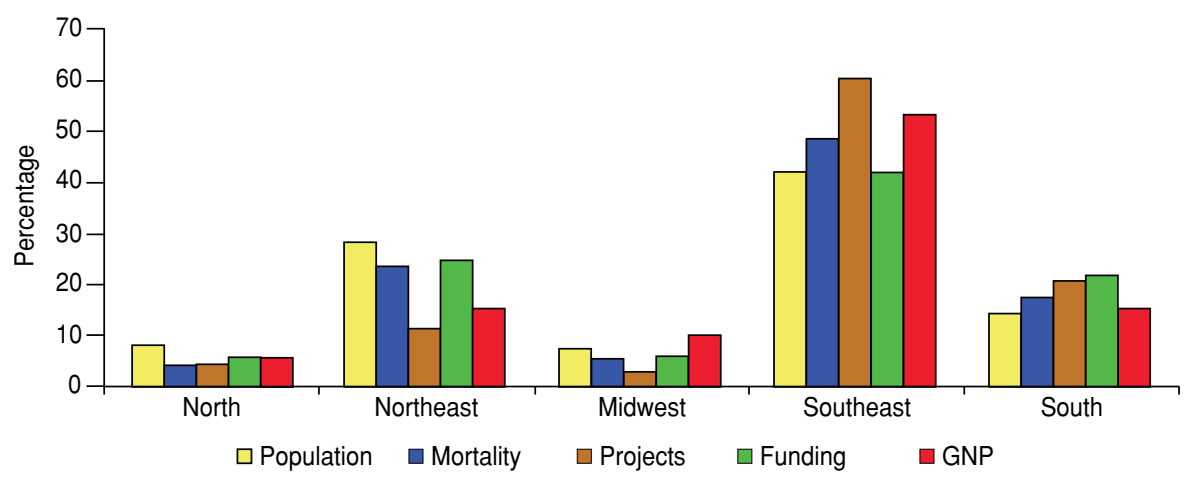

its partners awarded a US\$ 3.6 million grant to a biomedical and clinical project to develop humanized monoclonal antibody constructs designed to treat ovarian cancer. Some promising results from the study that were recently published make the IgG humanized anti-CD3 an attractive candidate for phase I/II clinical trials (8).

The threat of obesity is twofold as it can cause other CNCDs (e.g., 17\% of cancer cases are related to obesity). Obesity affects children, adolescents, adults, and the elderly-male and female, rich and poor-and is prevalent throughout the country. Recent data from the Brazilian Institute of Geography and Statistics (Instituto Brasileiro de Geografia e Estatística, IBGE) for 2008-2009 showed that 10 million Brazilians were obese according to body mass index (BMI) values ( $\geq 30$ $\mathrm{kg} / \mathrm{m}^{2}$ ) (9). Cross-sectional national surveys (also conducted by IBGE) collected anthropometric data for adults in 1974-
1975, 1989, and 2002-2003. Obesity prevalence has grown in the past few decades (affecting $4.4 \%$ of adults in 1974-1975 and $11.1 \%$ in 2002-2003-a 2.5-fold increase) and continues to rise. Prevalence of morbid obesity (BMI $\geq 40 \mathrm{~kg} / \mathrm{m}^{2}$ ) has expanded even faster, with a 3.5-fold increase over the same period (from $0.18 \%$ to $0.64 \%$ ) (10). Obesity research funded by DECIT included studies on prevalence, risk, and protection factors; comorbidity; impact of interventions; and bariatric surgery. Between 2002 and 2009, DECIT earmarked US\$ 4.6 million for the study of obesity. One randomized controlled trial targeted a very poor and obese slum population. Results showed that a moderately intense and structured exercise program, when sustained for six months, resulted in modest but significant weight loss in women, compared to the control group (11). The authors pointed out the policy implications of the considerable cost savings (in
US\$) that could be achieved through the use of such a simple and effective health promotion activity.

Estimates indicate that 1 out of every 3 individuals in Brazil has the medical condition known as hypertension. Hypertension is one of the most important risk factors for CNCD and occurs most often among individuals who are overweight or have diabetes, dyslipidemia, or cardiovascular problems. Hypertension is associated with age; education (favoring the less educated); race; and marital status (favoring widowed individuals). DECIT has awarded US\$ 12.3 million in total funding (about US\$ 2 million per year) to a research initiative on hypertension and hypertension-associated comorbidities (e.g., diabetes and obesity), including metabolic syndrome. This initiative led to the development of large national projects such as ERICA (Estudo de Riscos Cardiovasculares em Adolescentes), a study of CNCD risk factors in 
adolescents (12); PREVER (Hypertension Prevention in Pre-Hypertensive Individuals), a clinical trial for prehypertensive patients (13) with a highly accessed protocol; and ReHOT (Resistant Hypertension Optimal Treatment), a clinical trial for resistant hypertension (14).

Like obesity, diabetes is a common risk factor for many other CNCDs, in addition to being a severe disease on its own. Estimated prevalence was $7.3 \%$ in 2006 (15). Women are more inclined to have diabetes than men. Basic education on self-care, together with the use of highly technological aids, helps to control the disease, decreasing its incidence and diminishing mortality. Diabetes projects funded by DECIT varied widely, ranging from basic scientific research (e.g., phytochemistry studies) to high-technology R\&D. All in all, through the end of 2009, DECIT granted almost US\$ 13.4 million for diabetes research. Funds provided by DECIT allowed for the world's first stem cell treatment for type 1 diabetes mellitus. The authors of the study reported that 14 out of 15 patients became insulin independent after treatment (16), and the effects of treatment remained for an average of 31 months in 12 of the 20 study subjects (the eight relapsed patients required low doses of insulin) (17).

Across the Americas region, CNCDs (particularly cardiovascular diseases, hypertension, diabetes, and some cancers) are the leading cause of death. Brazil's support of research in this area has helped produce epidemiologic profiles and surveillance, cost, and qualityof-life data as well as many other types of results. From 2002 to 2009, DECIT and its partners invested US\$ 14516 603 in research on CNCDs in general. ELSA (Estudo Longitudinal de Saúde do Adulto [Longitudinal Study of Adults' Health]), a multicenter research project on diabetes in Brazilian adults that has been under development since 2005, has received more than US\$ 13 million from DECIT for the first round of the study. This epidemiologic cohort study will follow 15000 adults aged 35 to 74 with diabetes and cardiovascular disease.

The Brazilian government has developed a strong policy response with regard to CNCD risk factors, including smoking. In 2010, smoking prevalence was $17.9 \%$ in men and $12.7 \%$ in women (15). Brazil's tobacco control programs, and the recently enacted drunk-driving law, are good examples of proactive Brazilian policies (18). The drunk-driving law was based on the results of the Brazilian Surveillance System of Risk and Protective Factors for Chronic Diseases by Telephone Interview (Vigilância de Fatores de Risco e Proteção para Doenças Crônicas por Inquérito Telefônico), known as VIGITEL. VIGITEL was carried out in 2006, drawing from U.S. experience with the Centers for Disease Control and Prevention (CDC) Behavioral Risk Factor Surveillance System (BRFSS) (19). The VIGITEL pilot study was financed by DECIT (20). Investments by DECIT and its partners in research on CNCD risk factors amounted to US\$ 3397243 for the 2002-2009 period.

From 2002 to 2009,3000 projects were supported by the Brazilian Ministry of Health, and $16.8 \%$ of these focused on CNCDs. In addition to projects specifically targeting $\mathrm{CNCDs}$, related projects registered as other areas of study (e.g., women's health, child health, elderly health, indigenous peoples' health, etc.) were classified as CNCD projects in the current analysis. Although DECIT research support represents only a small portion of Brazil's GNP, the output from its efforts has a significant effect on public health because its mandate is restricted to generating scientific evidence for the SUS.

In addition to DECIT, Brazilian health research receives support from other Ministry of Health departments; Ministries (e.g., Education and Science \& Technology); and public and private sector entities, along with state health departments and agencies, and international organizations and agencies (1).

Currently, DECIT financing represents more than $50 \%$ of all national health research funding (21) and continues to grow (e.g., current DECIT funding for health research is about three times higher than what it supplied from 2003 to 2005). Although the monetary value is modest, this funding is sufficient to support the SUS framework.

Among all CNCD projects, the research topic funded mostly often was cancer, which received $26.2 \%$ of DECIT's CNCD research support and comprised $37.4 \%$ of all projects. More than $41 \%$ of the total funding was designated to research institutes in the Southeast, a region with more than $40 \%$ of Brazil's pop- ulation, and about $4 \%$ was earmarked for institutes in the Midwest region, which is home to approximately $7 \%$ of the population. The large proportion of funding designated to the Southeast can be partly attributed to the fact that the research coordinators for many of Brazil's large national projects (e.g., ELSA, MiHeart, ERICA, and ReHOT) are located in that region, due to its high scores for various health indicators, including those related to CNCDs. In addition, as mentioned above, many DECIT-supported projects based in the Southeast and other regions were national in scope.

In the North region, $69.0 \%$ of DECIT CNCD funding went to cardiovascular disease projects, versus $31.6 \%$ in the Northeast and $82.9 \%$ in the Midwest. In the Southeast, $30.4 \%$ of the DECIT funding went to cancer research. In the South region, $23.5 \%$ went to diabetes projects. In terms of number of projects, cancer was the top priority in all regions, with the proportion of total projects ranging from $29.9 \%$ in the Northeast to $56.4 \%$ in the Midwest. The projects covered a broad spectrum of topics, including disease distribution (and determining factors); access to health and diagnostic services; technology innovation and assessment; genetic and therapeutic development; economic costs and sustainability; pharmacological assistance; communication and information; education and environment; and ethical and methodological issues.

Over the last decade, CNCD research developed in Brazil has focused on health knowledge, technology, and innovation. Although DECIT's funding for CNCD research represents only $19.5 \%$ of Brazil's total health research support, the per-capita investment is double that of Uruguay, six times that of Bolivia, 12 times that of Paraguay, and slightly less than half of the total amount of spending on CNCD research by Chile and Argentina (22).

Research on CNCDs in Brazil is important because these diseases have emerged as the leading cause of death and a major contributor to the national disease burden. In addition, the CNCD epidemiologic profiles and risk factors observed in developed Western countries are not necessarily universal, so established CNCD prevention strategies are not necessarily transferable to Brazil and may require contextually specific solutions (23). 
To address these concerns, DECIT is helping to create a new scientific approach within the arena of health services and academia to help reduce CNCDs. As part of this effort, DECIT established a knowledge management entity (Coordenação de Gestão do Conhecimento, CGC) to process and disseminate evidence produced through DECITsponsored projects. Working in close partnership with the National Council of Municipal Health Secretaries (Conselho Nacional de Secretarios Municipais de Saude, CONASEMS), the CGC is responsible for producing seminars, reports, guides, and policy briefs (e.g., EVIPNet ${ }^{9}$ publications) targeting health managers to encourage the use of research evidence by SUS stakeholders.

The main limitation of the data presented in this article stems from delayed updates of the information management system on project completion status by the state and federal agencies that collaborate with DECIT. The completion of

\footnotetext{
9 Evidence Informed Policy Networks, established by WHO to promote the systematic use of highquality health research in policymaking in lowand middle-income countries.
}

state projects is often delayed due to revisions made to the original call for proposals in order to fully commit all funding.

While lack of information and inequalities in the occurrence and distribution of diseases remains a challenge, DECIT aims to help improve public health and quality of life in Brazil through its support of science and technology within the SUS framework. Successful achievement of this goal will require shared responsibility in promoting partnerships, developing effective strategies, and increasing transparency in Brazil's national health research system.

\section{REFERENCES}

1. Guimarães R, Santos LM, Angulo-Tuesta A, Serruya SJ. Defining and implementing a national policy for science, technology, and innovation in health: lessons from the Brazilian experience. Cad Saude Publica. 2006;22(4):1775-85.

2. World Health Organization. Preventing chronic diseases: a vital investment. Geneva: WHO; 2005.

3. Ministério da Saúde (BR). VIGITEL Brasil 2010: Vigilância de Fatores de Risco e Proteção para Doenças Crônicas por Inquérito Telefônico. Brasília: MS; 2011. Available at: http://portal.saude.gov.br/portal/arqui vos/pdf/vigitel_2010_preliminar_web. pdf

4. Azambuja MI, Foppa M, Maranhão MF, Achutti AC. Impacto econômico dos casos de doença cardiovascular grave no Brasil: uma estimativa baseada em dados secundários. Arq Bras Cardiol. 2008;91(3):148-55, 163-71.

5. Tura BR, Martino HF, Gowdak LH, dos Santos RR, Dohmann HF, Krieger JE, et al. Multicenter randomized trial of cell therapy in cardiopathies-MiHeart Study. Trials. 2007;8:2.

6. McMahon DS, Singer PA, Daar AS, Thorsteinsdóttir H. Regenerative medicine in Brazil: small but innovative. Regen Med. 2010;5(6):863-76.

7. Instituto Nacional de Câncer (BR). Brasil terá quase meio milhão de novos casos de câncer em 2010 [press release]. Oct 24. Rio de Janeiro: INCA; 2009. Available at: http:/ / www. inca.gov.br/releases/press_release_view. asp?ID $=2282$

8. Serpieri $\mathrm{F}$, Inocencio A, de Oliveira JM, Pimenta AA Jr, Garbuio A, Kalil J, et al. Comparison of humanized IgG and FvFc anti-CD3 monoclonal antibody expressed in $\mathrm{CHO}$ cells. Mol Biotech. 2010;45(3):218-25.

9. Instituto Brasileiro de Geografia e Estatística (BR). Pesquisa de orçamentos familiares 20082009: antropometria e estado nutricional de crianças, adolescentes e adultos no Brasil. Rio de Janeiro: IBGE; 2010. Available at: http:// www.ibge.gov.br/home/estatistica/popula cao/condicaodevida/pof/2008_2009_encaa/ pof_20082009_encaa.pdf

10. Santos LM, de Oliveira IV, Peters LR, Conde WL. Trends in morbid obesity and in bariatric surgeries covered by the Brazilian public health system. Obes Surg. 2010;20(7): 943-8.

11. Alves JG, Gale CR, Mutrie N, Correia JB, Batty GD. A 6-month exercise intervention among inactive and overweight favela-residing women in Brazil: the Caranguejo Exercise Trial. Am J Public Health. 2009;99(1):76-80.

12. Projeto ERICA. Estudo de Riscos Cardiovasculares em Adolescentes [homepage on the Internet]. Rio de Janeiro: Instituto de Estudos em Saúde Coletiva, Universidade Federal do Rio de Janeiro; c2011. Available at: http:// projetoerica.wordpress.com

13. Fuchs FD, Fuchs SC, Moreira LB, Gus M, Nóbrega AC, Poli-de-Figueiredo $C E$, et al. Prevention of hypertension in patients with pre-hypertension: protocol for the PREVERprevention trial. Trials. 2011;12(1):65. Available at: http://www.trialsjournal.com/con tent $/ 12 / 1 / 65$

14. Krieger EM. Multicenter trial of hypertensive patients for the identification of resistant hypertension and therapeutic standardization [abstract]. São Paulo: Instituto do Coração; 2010. Available at: http://www.bv.fapesp. $\mathrm{br} / \mathrm{en} /$ projetos-politicas-publicas / 7332/ multicenter-trial-hypertensive-patientsidentification

15. Pinto MEB. Estimativa do número de pessoas com diabetes no Brasil em 2006: projeções de 1986-1988 a partir de mudanças demográficas e nutricionais. Porto Alegre: Universidade Federal do Rio Grande do Sul; 2006. Available at: http://www.lume.ufrgs. $\mathrm{br} /$ handle/10183/8760

16. Voltarelli JC, Couri CE. Stem cell transplantation for type 1 diabetes mellitus. Diabetol Me- tab Syndr. 2009;1(1):4. Available at: http:// www.dmsjournal.com/content/1/1/4

17. Couri $C E$, Oliveira $M C$, Stracieri $A B$, Moraes DA, Pieroni F, Barros GM, et al. C-peptide levels and insulin independence following autologous nonmyeloablative hematopoietic stem cell transplantation in newly diagnosed type 1 diabetes mellitus. JAMA. 2009;301(15):1573-9.

18. Moura EC, Malta DC, Morais Neto OL, Penna GO, Temporão JG. Motor vehicle driving after binge drinking, Brazil, 2006 to 2009. Rev Saude Publica. 2009;43(5):891-4.

19. Centers for Disease Control and Prevention (US). Behavioral Risk Factor Surveillance System (BRFSS) [Internet]. Available at: http:// www.cdc.gov/BRFSS

20. Monteiro CA, Moura EC, Jaime PC, Lucca A, Florindo AA, Figueiredo IC, et al. Monitoramento de fatores de risco para doenças crônicas por entrevistas telefônicas. Rev Saude Publica. 2005;39(1):47-57.

21. Ministério da Saúde, Departamento de Ciência e Tecnologia, Secretaria de Ciência, Tecnologia e Insumos Estratégicos (BR). Pesquisa em saúde no Brasil. Rev Saude Publica. 2008;42(4):773-5.

22. Maceira D, Paraje G, Aramayo F, Mais SD, Sánchez D. Financiamiento público de la investigación en salud en cinco países de América Latina. Rev Panam Salud Publica. 2010;27(6):442-51.

23. Schooling CM, Leung GM. A socio-biological explanation for social disparities in noncommunicable chronic diseases: the product of history? J Epidemiol Community Health. 2010;64(11):941-9.

Manuscript received on 3 March 2011. Revised version accepted for publication on 1 August 2011. 
RESUMEN En el Brasil, las enfermedades crónicas no transmisibles (ECNT) son la principal causa de mortalidad y un factor contribuyente muy importante a la carga de morbilidad nacional. En este artículo se describe la investigación en ECNT financiada por el De-

Investigación sobre las enfermedades crónicas no transmisibles en el Brasil: responder a los retos de la transición epidemiológica

Palabras clave partamento de Ciencia y Tecnología del Ministerio de Salud (DECIT) para apoyar la producción y la difusión de información científica destinada al sistema nacional de salud, en conformidad con el Programa Nacional de Prioridades en Investigación de Salud y dentro del contexto de la transición epidemiológica del Brasil.

Los datos se obtuvieron a partir de los sistemas de manejo de bases de datos del Ministerio de Salud. Los proyectos relacionados con las ECNT financiados por el DECIT entre el 2002 y el 2009 fueron analizados por tema de investigación (cáncer, obesidad, hipertensión, diabetes, enfermedades cardiovasculares, ECNT en general y factores de riesgo de ECNT) y por región geográfica.

En cuanto al financiamiento y el número de proyectos, el tema de investigación más apoyado fue el cáncer, y la región más apoyada fue el sudeste del país. El tipo de proyecto varió ampliamente, e incluyó desde estudios científicos básicos hasta estudios de investigación y desarrollo muy técnicos. Los resultados obtenidos incluyeron perfiles epidemiológicos y datos de vigilancia, costos y calidad de vida.

Enfermedad crónica; política de salud; política de investigación en salud; sistemas de información; transición de la salud; Brasil. 